\title{
Risks in the Credit Process, Prevention Methods and their Coverage
}

\author{
Viorica IOAN ${ }^{\star}$, Costinela FORTEA $\star \star$
}

\begin{tabular}{l}
\hline \multicolumn{1}{c}{ A R T I C L E I N F O } \\
\hline Article history: \\
Accepted June 2019 \\
Available online August 2019 \\
\hline JEL Classification \\
G20, G21 \\
Keywords: \\
Bank risks, Operational risk, \\
Indicators, Supervision, Fraud, \\
Credit institutions
\end{tabular}

\begin{abstract}
A B S T R A C T
This paper provides an overview of credit risk assessment and operational risk prevention and coverage methods. Bank management is based on profit maximization and risk minimization objectives. The level of profit obtained by a bank is also a direct consequence of the type of strategy adopted in the bank's management in the sense of accepting or not the risks in the performed activity. The risk of unexpected losses are treated as recorded in the banking business developments due to the registration of the results to the effects anticipated. Operational risk is the danger of unexpected losses, a result of the action of the bank's internal and external factors affecting conducting operational activity. So, we are presented methods of prevention and operational risk coverage.
\end{abstract}

(C) 2019 EAI. All rights reserved.

\section{Introduction}

Risk is a constant, inherent component of the activity of banking institutions. Banking risk expresses the probability that there may be adverse effects on the business during the activities of the banking institution, which may be in the form of loss of profits, losses, bank failures or bankruptcy.

\section{Risk in the credit process}

Bank Risk Management supervises its identification, measurement, analysis and control system, reduce the negative influences of risk faces in the planning phase and minimize losses in the operational execution phase of the strategic plan undertaken. The Bank seeks to maximize its profit while maintaining risk to an acceptable level. The activity can accept only bank exposures, and do not assume any risk individually or cumulatively that can not be measured or the consequences of which could prejudice the bank. In the management and tracking of bank risk is recommended to use a methodology that includes several steps: identification, measurement, control and monitoring..

\section{Figure number 1. Cyclical banking risk control process}

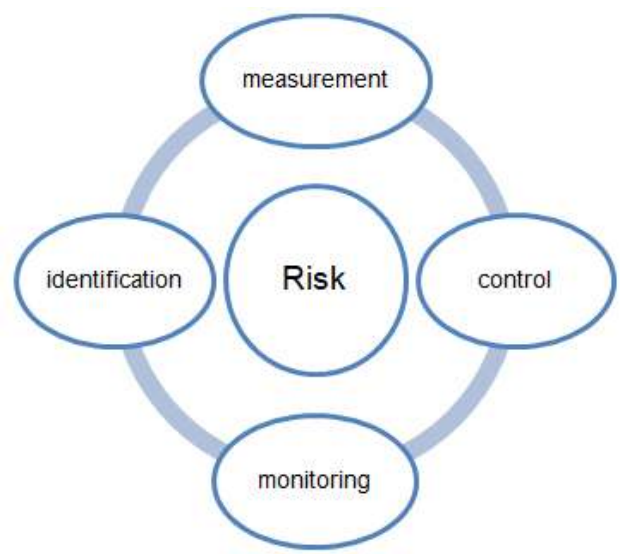

Source: Developed by author 
In general, banking risks are grouped into four categories: financial risks, operational risks, business risks and risks of the occurrence of events. Financial risks include two types of risk: pure risks, including liquidity risk, credit risk and solvency risk, may result in a loss to the banking institution if it is not properly managed. And speculative risks, including: interest rate risk, currency risk and market position risk, are based on financial arbitrage and can result in profit, in the case of fair arbitrage or loss, if arbitration is incorrect. Operational risks are produced by events as a result of the influences of internal and external factors that may affect the achievement of the Bank's objectives. Business risks are associated with the environment in which the credit institution operates, including macroeconomic and policy concerns, as well as legal and regulatory factors. The risks of occurrence of events include all categories of exogenous risks, which, if materialized, could endanger the operations of a bank.

During the activity, the banks are subject to a wide variety of risks, as shown in Figure 2.

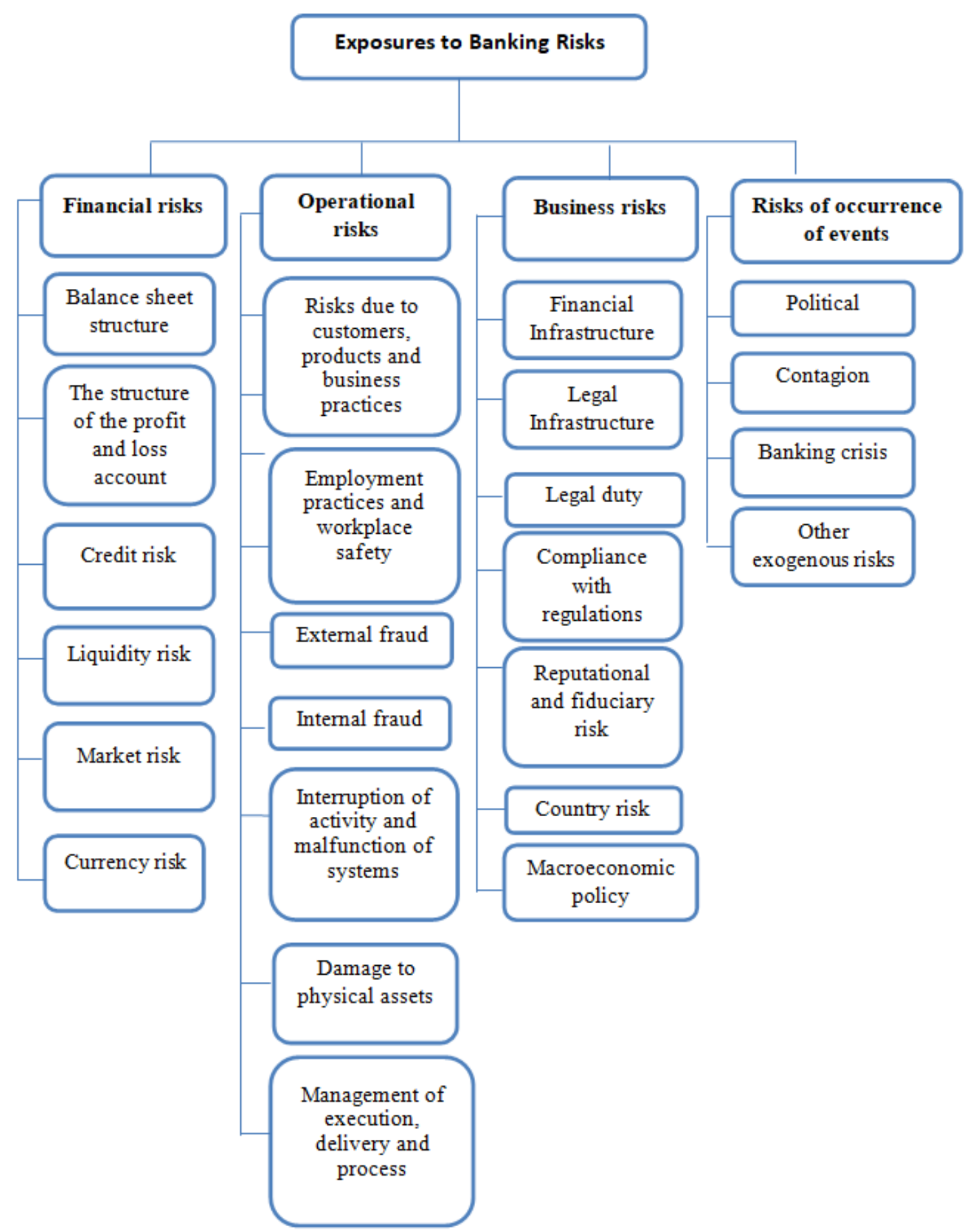

Figure 2. Banking risks 
The lending activity should be carried out in the banking companies on the basis of well defined credit granting conditions. Banks must have well-established processes for approving new loans, changing clauses, or renewing and refinancing existing ones.

\begin{tabular}{|c|c|c|}
\hline \multirow{6}{*}{ SOLVENCY } & $>15 \%$ & \multirow{3}{*}{ Tier 1 own funds rate } \\
\hline & [12\%-15\%] & \\
\hline & $<12 \%$ & \\
\hline & $>14 \%$ & \multirow{3}{*}{ Rate of basic level 1 own funds } \\
\hline & [11\%-14\%] & \\
\hline & $<11 \%$ & \\
\hline \multirow{9}{*}{$\begin{array}{l}\text { CREDIT RISK AND ASSET } \\
\text { QUALITY }\end{array}$} & $<3 \%$ & \multirow{3}{*}{$\begin{array}{l}\text { The rate of non-performing loans and } \\
\text { advances }\end{array}$} \\
\hline & [3\%-8\%] & \\
\hline & $>8 \%$ & \\
\hline & $>55 \%$ & \multirow[t]{3}{*}{ The coverage ratio with non-performing loans } \\
\hline & [40\%-55\%] & \\
\hline & $<40 \%$ & \\
\hline & $<1,5 \%$ & \multirow{3}{*}{$\begin{array}{l}\text { Rate of loans and advances with restructuring } \\
\text { measures }\end{array}$} \\
\hline & [1,5\%-4\%] & \\
\hline & $>4 \%$ & \\
\hline \multirow{6}{*}{ PROFITABILITY } & $>10 \%$ & \multirow{3}{*}{ Rate of financial return } \\
\hline & {$[6 \%-10 \%]$} & \\
\hline & $<6 \%$ & \\
\hline & $<50 \%$ & \multirow{3}{*}{ Efficiency indicator of activity } \\
\hline & {$[50 \%-60 \%]$} & \\
\hline & $>60 \%$ & \\
\hline \multirow{5}{*}{$\begin{array}{l}\text { BALANCE SHEET } \\
\text { STRUCTURE }\end{array}$} & $<100 \%$ & \multirow{3}{*}{ Loans and advances / Total deposits } \\
\hline & [100\%-150\%] & \\
\hline & $>150 \%$ & \\
\hline & $\frac{<12 \mathrm{x}}{[100 \mathrm{x}-150 \mathrm{x}]}$ & \multirow[t]{2}{*}{ Total Debt / Total Equity } \\
\hline & $>15 x$ & \\
\hline \multicolumn{3}{|l|}{ BEST } \\
\hline \multicolumn{3}{|l|}{ INTERMEDLARY } \\
\hline THE WORST & & \\
\hline
\end{tabular}

Figure 3. The prudence of risk indicators, established by ABE Source: National Bank of Romania

Figure 3 shows the indicators grouped into four categories: solvency, profitability, asset quality and balance sheet structure. Therefore, each indicator is evaluated according to three prudence intervals, its value being considered very good, intermediate or deficient in relation to the value range to which it belongs.

Table 1. Indicators on credit institutions

\begin{tabular}{|c|c|c|c|c|c|}
\hline Name & Dec.2014 & Dec.2015 & Dec.2016 & Dec.2017 & Dec.2018 \\
\hline $\begin{array}{lll}\begin{array}{l}\text { Number } \\
\text { institutions }\end{array} & \text { of } & \text { credit } \\
\end{array}$ & 40 & 36 & 37 & 35 & 34 \\
\hline Branches of foreign banks & 9 & 7 & 8 & 7 & 7 \\
\hline Total Net Assets & $364.143,30$ & $377.187,20$ & $393.647,91$ & $427.792,57$ & $451.144,47$ \\
\hline Solvency ratio (\%) & 17,59 & 19,16 & 19,68 & 19,97 & 19,66 \\
\hline The leverage effect (\%) & 7,38 & 8,18 & 8,92 & 8,89 & 8,81 \\
\hline ROA & $-1,32$ & 1,24 & 1,08 & 1,3 & 1,59 \\
\hline ROE & $-12,45$ & 11,77 & 10,42 & 12,51 & 14,85 \\
\hline $\begin{array}{lll}\begin{array}{l}\text { Profitability } \\
\text { business (\%) }\end{array} & \text { of } & \text { core }\end{array}$ & 180,19 & 171,31 & 188,57 & 181,62 & 186,92 \\
\hline
\end{tabular}




\begin{tabular}{|l|c|c|c|c|c|}
\hline \multicolumn{1}{|c|}{ Name } & Dec.2014 & Dec.2015 & Dec.2016 & Dec.2017 & Dec.2018 \\
\hline $\begin{array}{l}\text { Loans / deposits attracted } \\
\text { by customers (\%) }\end{array}$ & 91,33 & 85,39 & 79,05 & 74,74 & 73,56 \\
\hline $\begin{array}{l}\text { Depreciated receivables / } \\
\text { total loan portfolio }\end{array}$ & 9,39 & 7,04 & 4,89 & 3,02 & 2 \\
\hline $\begin{array}{l}\text { The rate of non-performing } \\
\text { loans as defined by ABE }\end{array}$ & 20,71 & 13,51 & 9,62 & 6,41 & 4,95 \\
\hline
\end{tabular}

Source: National Bank of Romania

The graph highlights the evolution of the indicators in Figure 2.

Figure 4. Evolution of Credit Institution Indicators

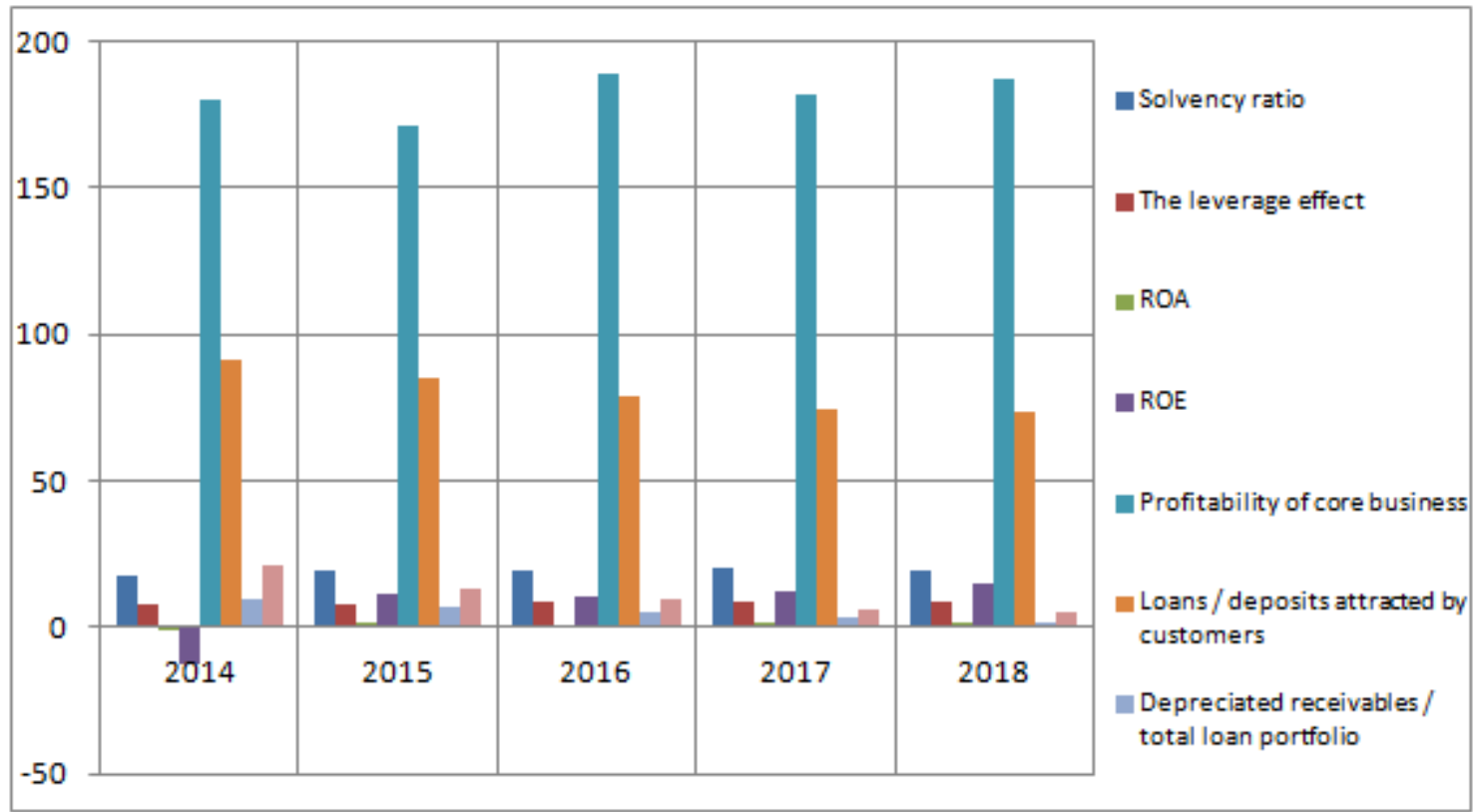

Source: Developed by author

In the analyzed period, 2014-2018, we see a fluctuating trend indicators on credit institutions. Thus, the solvency ratio recorded a fluctuating evolution in the analyzed range, with the lowest value being $17.59 \%$ in 2014 and the highest value being recorded in 2017, respectively $19.97 \%$. The profitability of the core activity recorded fluctuating values during this period, with the highest value in 2016 respectively $188.57 \%$ and the lowest value in 2015 respectively $171.31 \%$. The data also shows an improvement in profitability indicators, with ROE growing and the best range caution range in 2018.

\section{Methods of prevention / mitigation of operational risk}

1. Internal fraud

\section{$\checkmark$ Bank failure attempt:}

* ensuring banking units with mechanical-physical and electronic protection factors;

* ensure appropriate work spaces and properly equipping units with cabinets and safes for keeping documents and valuables safe;

* security by specialized personnel;

\# regulation of the person's access system to the bank.

\section{$\checkmark$ Reporting in bad faith of operations:}

* regular analysis of income and expense accounts, in terms of structure and content;

* the constant analysis of the balances of accounts of debtors and creditors;

* control of data submitted by territorial units, after multiple control keys, to avoid the risk of bad faith reporting of transactions;

* performing a double technical-operative check on the operations carried out;

$\checkmark$ Theft of documents:

* keeping values and documents in safes and controlling them regularly;

* drafting and using the provisions of the bank's internal regulations on ensuring the security;

* restricting and checking access to areas with significant risk; 
* video recording of all entries in bank units;

* the entrance to the document rooms shall be secured by access by a cipher or a card;

$\checkmark$ Execution by employees of transactions in their name and in their own account:

* validation of debit transactions of clients' accounts

* regularly checking the operations performed with self-validation by client managers on client accounts;

* regular checking of remote operations on client accounts

* reducing access to user operations by determining application-level access profiles;

* setting up working commissions to advise on the development of investment and repair works;

* the establishment and introduction of codes of conduct for banking workers involved in operations that may create operational risk manifestations;

\section{External fraud}

\section{$\checkmark \quad$ Computer fraud:}

* protecting the bank's portal against attacks from outside;

* the proper protection of the communication channels and related equipment used by the bank;

* establishing access to the personalized electronic area of the bank via a secure https connection;

* adequate protection of communication channels and equipment used by the bank;

Forging documents / instruments of payment:

using the bank's internal procedures in the field of customer knowledge;

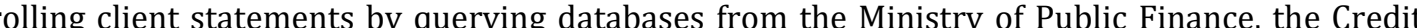
Bureau, the Trade Register Office, the Banking Risk Center and other sources of official information; check databases on customers, payment documents falsified or entities suspected of terrorism; communications received through SWIFT on falsified documents entered into the national or international banking circuit should be transmitted on the same day to the operating departments and branches;

drafting letters of information on banknote safety features;

The attempted robbery / theft:

providing units with mechanical-physical and electronic protection factors;

* providing adequate working space and properly equipping units with cabinets and safes for keeping documents and valuables safe;

* providing security by specialized personnel;

3. Conditions for hiring personnel and job security:

\section{$\checkmark \quad$ Security of the space where the cashier activity is carried out:}

* equipped with bullet-proof glass or anti-burglary;

\# electronic protection systems;

* coded systems for access to the cashier;

\# regularly keep workplace safety instructions;

* making annual building and property insurance for risks such as fires, floods and earthquakes;

* performing the annual insurance of the vehicles from the bank's equipment against the risks of accidents;

\# the completion of insurance policies for values transportation.

\section{Bad customer-related practices, products and activities:}

$\checkmark \quad$ Preventing malfunctions / avoiding system interruptions:

* maintaining optimal temperature conditions for good system operation;

* configuration of critical communications equipment and data or application servers, tasks can be retrieved between equipment in required cases;

performing backup procedures for computer and communication systems;

performing complex monitoring and event detection systems of any kind;

receiving and immediately distributing incidents alerted by a specialized structure; setting up IT staff to supervise the functioning of computerized systems;

* functional service contracts concluded with companies specialized equipment and the names of persons to follow up the contracts;

Preventing system viruses:

$\quad$ Preventing system viruses:
$+\quad$ reporting to the IT Department by the directions reporting the malfunctions / interruption of the activity;

Regular updating with the latest versions of antivirus software;

\section{Preventing loss of information}

saving documents / information on external support;

creating a backup and restore policy that matches the rules; 


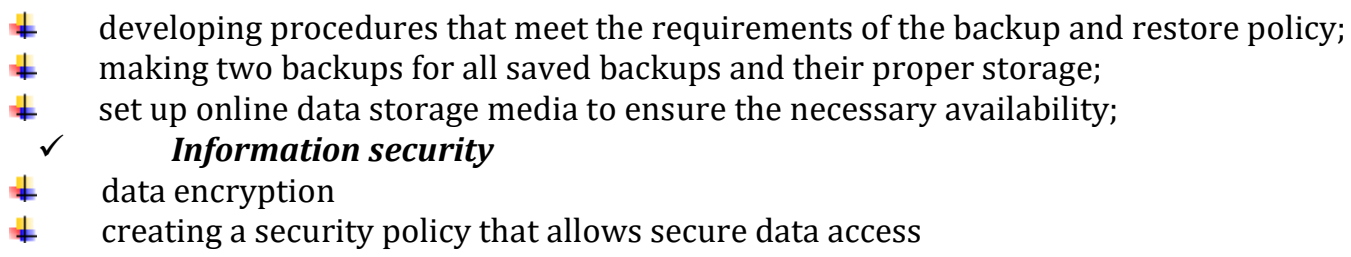

\section{Threat of tangible assets}

$\checkmark \quad$ Selling unauthorized products, contract errors, contract mistakes, new product risks, and changes to existing ones:

* conducting actions to guide the activity within the departments of the bank;

* organizing courses and informing with operative units;

* the introduction of SWIFT messages by one person and validation by another person;

$\checkmark \quad$ Non-compliance with the confidentiality of operations:

* access to authentication and authorization information;

* introduction of keeping the confidentiality clauses;

* the contracts that are concluded with the suppliers of equipment and services are made together with the specialized department;

Non-compliance with customer-related products and services:

compliance of the internal rules on keeping confidentiality;

compliance with the ethical code of the assessor;

Risks related to the accuracy of the amounts collected / paid by customers, in lei / currency: equipping with machines for counting and sorting banknotes;

periodic change of employees at the counter;

The sale of unauthorized products / errors in the procurement / contracting, implementation errors / risks related to new products or modify the existing ones: carrying out guidance actions by specialized departments; the constant pursuit of the use of funds for the purposes for which they were granted; the use of standardized formats in the preparing of the documentation;

\section{Interruption of activity and malfunction of systems}

\section{Human errors:}

the creation of posts aimed at validating the operations performed by the front-office staff;

determining cyber methods and organizational modalities;

the exercise of redistribution of personnel between units;

7. Treatment of customers and commercial counterparties and defective processing of data concerning them:

Measures to reduce / mitigate the risks related to bank customers:

* in order to minimize the risk of inaccurate data recording / incomplete documentation: systematization of guidance and verification actions by specialized departments;

Incomplete documentation

double document verification;

requesting information to the Investigation Service / Customer / the party that provided the documents;

setting up guidance actions;

checking during documentation checks on documentation that does not reach the Central Office;

Litigation / claims / complaints:

management in accordance with internal procedures for petitions, with a view to resolving notifications and complaints;

\section{Information security}

* compliance with internal regulations on information security;

\section{External factors}

examination of operational risk events produced in other banking systems, with the same degree of development

continuous supervision of the legislation, economic conditions that can influence the banking activity.

In the case of minimizing operational risk, the bank sets up optimal correction procedures for operational risk errors. Banks are also required to take steps to increase the security of information processed within the units and at the level of the bank's central administration. 


\section{References}

1. Basno C., Nicolae D., Constantin F.- Monedă.Credit.Bănci, Editura Didactică și Pedagogică, București, 2003.

2. Basno.C, Dardac. N.- Sisteme de Plăti, Compensări și Decontări, Editura Didactică și Pedagogică, București, 2003.

3. Bădulescu D.,- Globalizarea și băncile, Editura Economică, București, 2007.

4. Bătrâncea I., Trenca I., Bejenaru A., Borlea S.N. - Analiza performanțelor și riscurilor bancare, Editura Risoprint, Cluj-Napoca, 2008.

5. Bătrâncea I., Moscviciov A., Bătrâncea L., Popa A., Nichita A.- Analiza financiară în bănci, Editura RISOPRINT, Cluj-Napoca, 2010, pag.335

6. Beju D.-Politici monetare, Editura Casa Cărții de Stiință, Cluj-Napoca, 2006.

7. Beju D.- Mecanisme Monetare și Instituții Bancare, Editura Casa Cărții de Știință, Cluj-Napoca, 2005.

8. Berea A.O.- Strategie bancară, Editura Expert, București, 2001.

9. Calle E. - Banking Risks-Reducing uncertainty to Improve Bank Performance, Fitzroy Derborn Publishers, Chicago, SUA, 1999.

10. Căpraru B.-Activitate bancară: Sisteme, operațiuni și practici, Editura C.H.Beck, București, 2010.

11. CocrișV.- Economie bancară: repere teoretice și studiu monogrrafic, Editura Universității Al.I.Cuza, Iași, 2007.

12. Cohen E-- Analyse financiere, Les Editions d'Organisation, Paris, 1995.

13. Dănilă N., Berea A.O.- Managementul bancar: fundamente și orientări, Editura Economică, București, 2000

14. Dardac N., Barbu T.- Monedă, Bănci și Politici monetare, Editura Didactică și Pedagogică, R.A., București, 2006.

15. Hoanță N.- Bani ți Bănci, Editura Economică, București, 2001.

16. Hennie van Greuning, Sonja Brajovic Bratanovic- Analiza și Managemetul riscului bancar (Analyzing and Managing banking risk), Editura IRECSON, București, 2003.

17. Lupasc I., Baragan L.A., Aspects concerning the relationship between internal audit and fraud risk, International Conference Risk in Contemporary Economy, 2016, http://www.rce.feaa.ugal.ro/images/stories/RCE2016/LupascBaragan.pdf

18. Lupasc I., Finante si elemente de modelare financiara, Editura Europlus, Galati, 2013

19. Nițu I.-Managementul riscului bancar, Editura Expert, București, 2000, pag.34.

20. Kirițescu C.C., Dobrescu M.E.- Băncile, mica enciclopedie, Editura Expert, București, 2001.

21. Spulbăr C.M.- Optimizarea managementului bancar, Editura Universiatria, Craiova, 1999.

22. Stancu I.- Gestiune financiară, Editura Economică, București, 1994.

23. Trenca I. - Fundamente ale managementului financiar, Editura Casa Cărții de Știință, Cluj-Napoca, 2006.

24. Trenca I.- Metode și tehnici bancare, Ediția a II a , Editura Casa Cărții de Știință, Cluj-Napoca, 2006.

25. Turliuc V., Cocriș V., Boariu A., Stoica O., Dornescu V., Chirleșan D.- Monedă și credit, Editura economică, București, 2005.

26. Banca Națională a României - https://www.bnr.ro 